NOTE

\title{
Batrachochytrium dendrobatidis in the live frog trade of Telmatobius (Anura: Ceratophryidae) in the tropical Andes
}

\author{
Alessandro Catenazzi ${ }^{1, *}$, Vance T. Vredenburg ${ }^{2}$, Edgar Lehr \\ ${ }^{1}$ Department of Integrative Biology, University of California at Berkeley, 3060 Valley Life Sciences, Berkeley, \\ California 94707, USA \\ ${ }^{2}$ Department of Biology, San Francisco State University, San Francisco, California 94132, USA \\ ${ }^{3}$ Department of Biology, Illinois Wesleyan University, 303 East Emerson, Bloomington, Illinois 61701, USA
}

\begin{abstract}
Species of frogs in the genus Telmatobius are traded and sold for human consumption in the Andes and in coastal cities of Peru and Bolivia. These frogs are harvested from wild populations. We report high prevalence of infection by the pathogenic fungus Batrachochytrium dendrobatidis in live frogs purchased at the main market in Cusco, Peru, from January 2008 to January 2010. We suggest that the transport of native anurans through the live frog trade could facilitate the spread of this fungus among Andean frogs. The tropical Andes are the most important biodiversity hotspot for amphibians. Because many neotropical taxa are known to be susceptible to chytridiomycosis, the presence of a large reservoir of infection in the frog trade poses a significant threat to amphibian conservation.
\end{abstract}

KEY WORDS: Batrachochytrium dendrobatidis $\cdot$ Amphibians $\cdot$ Trade $\cdot$ Andes $\cdot$ Peru $\cdot$ High elevation

\section{INTRODUCTION}

The emerging infectious disease chytridiomycosis, caused by the fungus Batrachochytrium dendrobatidis $(B d)$, has been linked to amphibian declines and extinctions worldwide (Berger et al. 1998, Longcore et al. 1999, Lips et al. 2006). This fungus infects the skin of amphibians, causing osmotic imbalance leading to cardiac arrest (Voyles et al. 2009). Amphibian species differ in their vulnerability and resistance to chytridiomycosis (Alford \& Richards 1999, Daszak et al. 2003, Woodhams et al. 2007), but this disease often causes catastrophic and quick declines of species-rich amphibian faunas (Lips et al. 2006).

Neotropical montane amphibians have declined or collapsed over the past 3 decades (Lips 1998, Bustamante et al. 2005, La Marca et al. 2005, Catenazzi et al. in press). In at least one case in Central America, $B d$ caused the collapse of a highly diverse amphibian fauna on a single mountain (22 of 46 species disap- peared; Lips et al. 2006). Little is known about how $B d$ is spreading, but Lips et al. (2008) proposed that the temporal pattern of these declines reflects the epidemic spread of $B d$ from multiple sites of introduction in Central and South America. According to this hypothesis, $B d$ began infecting amphibians in the Andes of Peru and Bolivia around the year 2000, causing local and regional species extirpations. In support of this hypothesis, $B d$ has recently been discovered in this region in a number of amphibian species (Seimon et al. 2007, Barrionuevo et al. 2008, Venegas et al. 2008). Moreover, Catenazzi et al. (in press) reported $B d$ in 16 frog species surveyed between 2008 and 2010 in southeastern Peru.

The mechanism for the introduction and spread of $B d$ is still unknown, but one theory that has been proposed is that $B d$ is spread by live trade in amphibians for human consumption (Daszak et al. 2003, Weldon et al. 2004, Schloegel et al. 2009). Most of the attention has so far been focused on farming and trade in Litho- 
bates catesbeianus (Ranidae; Daszak et al. 2004, Garner et al. 2006). This species is known to carry $B d$, yet it is not known to die from chytridiomycosis, and is raised in farms around the world, including in South America (Mazzoni et al. 2003, Hanselmann et al. 2004, FAO 2009: www.fao.org/fishery/topic/2017/en). In this paper we investigate whether trade in native Andean species (captured in the wild, but traded alive) could be a source of $B d$ for wild populations.

Andean frogs in the genera Telmatobius and Batrachophrynus are traded in montane and coastal cities for food and because of presumed magical or medicinal properties (Lehr 2000, Angulo 2008a). The frogs are sold live, freshly skinned and degutted, dried, or prepared in frog 'shakes,' cooked in soups, or fried (Angulo 2008a). Presumed medicinal properties of frogs include treatment of neurological disorders or symptoms, anemia, prostate problems, menopausal disorders, and asthma in Cusco (Angulo 2008a) and treatment of respiratory diseases, arthritis, diabetes, frigidity, and hair loss, as well as aphrodisiac action, in Lima (Lehr 2000).

Peru and Bolivia harbor the highest diversity of Telmatobius species (Lehr 2005). These frogs are threatened by habitat destruction and modification, contamination from mining and agricultural practices, harvesting, introduced fish, and disease (Angulo 2008b, De la Riva \& Lavilla 2008, von May et al. 2008). The 3 Telmatobius spp. known from Ecuador were extirpated in the late 1980s and early 1990s and are now presumed to be extinct (Merino-Viteri et al. 2005). Symptoms of chytridiomycosis were observed in the last Telmatobius specimens collected in this region (Merino-Viteri et al. 2005). Chytridiomycosis has since been implicated in population declines of T. marmoratus from Peru (Seimon et al. 2007) and 2 Telmatobius spp. from Argentina (Barrionuevo \& Mangione 2006).

We propose that the trade of live Telmatobius frogs could facilitate the spread of $B d$ among wild populations in the tropical Andes. Wild Telmatobius frogs are harvested from lakes and streams and transported live to markets located up to hundreds of $\mathrm{km}$ away from their collecting sites. T. culeus, for example, is transported over several hundred $\mathrm{km}$ from Lake Titicaca to the main city market in Cusco in southern Peru (Angulo 2008a) and all the way to Lima (Lehr 2000). Here we report data on the prevalence of infection and zoospore load of $B d$ in $T$. marmoratus frogs sold live for human consumption in Cusco.

\section{MATERIALS AND METHODS}

We visited the San Pedro market in Cusco, Peru $\left(13^{\circ} 31^{\prime} 16^{\prime \prime} \mathrm{S}, 71^{\circ} 58^{\prime} 57^{\prime \prime} \mathrm{W}, 3410 \mathrm{~m}\right.$ above sea level) on 30 January 2008, 11 October 2008, 16 February 2009, and 3 January 2010. During each visit, we purchased 5 live adult Telmatobius marmoratus (the only species visibly on sale at the market during our visits) from a stand at the Cusco central market (there was only one stand operating during the course of our study). In addition, in 2009, the vendor donated skins of 9 recently skinned adults, which we also utilized in this study.

Live frogs ( 20 to 30 ind. per container) were housed in $10 \mathrm{l}$ plastic buckets filled with water (Fig. 1). The vendor was beheading, skinning, and gutting frogs for customers during visits; recently deceased, skinned frogs ready for consumption were also available at the stand. We recorded price, snout-vent length (SVL), body mass, and sex of each frog. We housed live frogs individually in plastic bags and swabbed them shortly after purchase. We used frog skin swabs and a realtime PCR assay to quantify $B d$ prevalence and infection intensity (Boyle et al. 2004). Swabs (MW113, Medical Wire and Equipment) were stroked across a frog's skin in a standardized way: 5 strokes on each side of the abdominal midline, 5 strokes on the inner thigh of each hind leg, and 5 strokes on the foot webbing of each hind leg. Swabs were air dried in the field and stored individually in labeled microcentrifuge tubes before PCR analysis. We used standard DNA extraction and real-time PCR methods (Boyle et al. 2004, Hyatt et al. 2007), except that swab extracts were analyzed in singlicate instead of triplicate (Kriger et al.

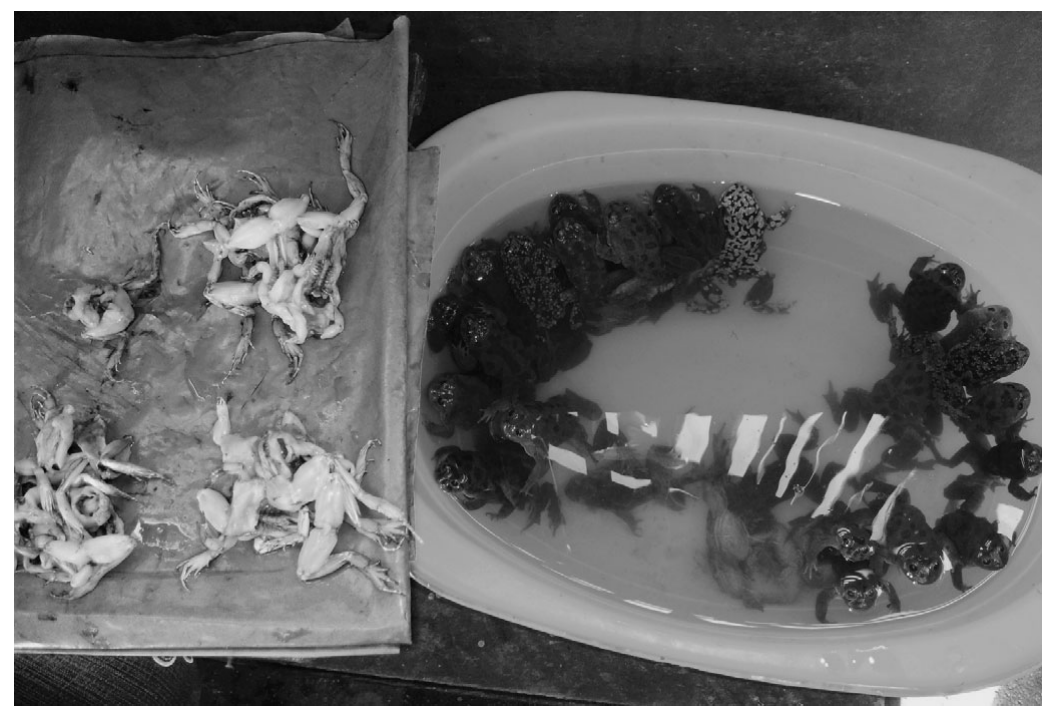

Fig. 1. Stand offering skinned and degutted and live Telmatobius marmoratus at the San Pedro market in Cusco, Peru, on 3 January 2010 
2006). We defined infection intensity as the number of 'zoospore equivalents' per swab $\left(Z_{\text {swab }}\right)$. Zoospore equivalents were calculated by multiplying the genomic equivalent values generated during the realtime PCR by 80 ; this multiplication accounts for the fact that DNA extracts from swabs were diluted 80-fold during extraction and PCR. For calculations of $B d$ prevalence, swabs were categorized as positive when zoospore equivalents were $\geq 1$ and $B d$-negative when zoospore equivalents were $<1$. Frogs were euthanized with a ventral cutaneous application of $20 \%$ benzocaine gel, fixed in formalin, and placed in $70 \%$ ethanol. Specimens have been deposited at the Museo de Historia Natural, Universidad Nacional Mayor de San Marcos, Lima.

\section{RESULTS}

All frogs (100\%) swabbed between January 2008 and January 2010 were infected with $B d$ ( $\mathrm{n}=20$; Table 1). $B d$-loads $\left(Z_{\text {swab }}\right)$ ranged between 9.76 and 101861.6 (Table 1). We detected $B d$ zoospores in 8 of 9 skins swabbed in February 2009, but $Z_{\text {swab }}$ was much lower than swabs of live frogs and ranged between 0.04 and 108.00 spores per swab in infected frogs. Three of 26 live frogs that were for sale on 3 January 2010 were dead (Fig. 1), but these frogs were not tested for $B d$ or examined for symptoms of chytridiomycosis.

The price of 1 live Telmatobius marmoratus frog was 1 Peruvian Nuevo Sol (PEN) during the 2008 and 2009 visits (equivalent to US\$ 0.33 on 30 January 2008, US\$ 0.32 on 11 October 2008, and US\$ 0.30 on 16 February 2009) and 2 PEN (or 5 PEN for 3 frogs) on 3 January 2010 (equivalent to US\$ 0.70 for 1 frog and US\$ 1.76 for 3 frogs). SVLs of purchased specimens ranged from 49.0 to $61.5 \mathrm{~mm}$ in January 2008, 50.2 to $61.8 \mathrm{~mm}$ in October 2008, 54.0 to $65.0 \mathrm{~mm}$ in February 2009, and 55.8 to $60.3 \mathrm{~mm}$ in January 2010. Most spec-

Table 1. Batrachochytrium dendrobatidis $(B d)$ infecting Telmatobius marmoratus. Prevalence of $B d$ infection in frogs sold for human consumption at the San Pedro market in Cusco, Peru. Data refer to live frogs except when otherwise noted (skins). $Z_{\text {swab: }}$ zoospore equivalents per swab (see 'Materials and methods')

\begin{tabular}{|lccl|}
\hline Date (season) & $\mathrm{N}$ & $\begin{array}{c}\text { Infection } \\
\text { prevalence }\end{array}$ & Median $Z_{\text {swab }}($ range) \\
\hline 30 January 2008 (rainy) & 5 & 1.00 & $218.8(32.6-4629.2)$ \\
11 October 2008 (dry) & 5 & 1.00 & $2018.4(296.0-60344.0)$ \\
16 February 2009 (rainy) & & & \\
$\quad$ Live frogs & 5 & 1.00 & $51.1(9.8-1799.2)$ \\
$\quad$ Skins & 9 & 0.89 & $0.4(0-108.0)$ \\
3 January 2010 (rainy) & 5 & 1.00 & $1022.4(65.6-101861.6)$ \\
\hline
\end{tabular}

imens were reproductive males bearing nuptial pads and excrescences, except for a female purchased in February 2009 and 3 females purchased in January 2010. According to the vendor, specimens in October 2008 and February 2009 originated from Ocongate, $65 \mathrm{~km}$ east of Cusco.

\section{DISCUSSION AND CONCLUSIONS}

All live Telmatobius marmoratus sampled during this study were infected with $B d$. This is the first report of captive T. marmoratus harboring infections in the trade of this species for human consumption. The high prevalence in our sampled animals might be explained by the fact that $B d$ has been known to infect wild populations of this species in the region since at least 2002 (Seimon et al. 2007). Additionally, the high prevalence could also be the result of frogs being housed in close contact with each other (e.g. in plastic buckets filled with water at the market; Fig. 1), which could promote transmission between individuals after capture. Simple measures, such as maintaining frogs in bleached water, could prevent transmission of $B d$ among individuals. However, these measures are unlikely to be adopted if the frogs for sale do not develop chytridiomycosis and die during the short period between capture in the wild and sale at the market.

The live trade of these native frogs is common throughout the Peruvian Andes, and we propose that this may be an important, but until now overlooked, factor involved in chytridiomycosis epidemics. The transportation of infected, live frogs over long distances could promote the spatio-temporal spread of $B d$ to naïve populations of amphibian hosts in the Andes. There are many ways this could happen. Water containing zoospores could be released when people transfer frogs between buckets or bags. Frog hunters could also contaminate sites with their boots or trapping equipment. Infected tadpoles or frogs could be translocated or released in the wild after capture, or they could escape. The concentration of frogs for trade could also maintain a reservoir of $B d$ when infection prevalence is low in wild populations. In addition, the frog trade could contribute to the spread of different genotypes of $B d$, some of which might be more virulent than others (Morgan et al. 2007).

Although we could not verify the source of Telmatobius marmoratus individuals sold live in the San Pedro market in Cusco, it is likely that all frogs originated from wild popula- 
tions. Captive breeding of 2 larger and economically more valuable species, T. culeus and Batrachophrynus macrostomus, has been unsuccessful (Pérez Béjar 2005), and there are no reports of attempted breeding of $T$. marmoratus. The putative geographic source of the frogs we purchased at the market, Ocongate, is close to sites with wild T. marmoratus populations surveyed by Seimon et al. (2007) and Catenazzi et al. (in press). Field data from Laguna Sibinacocha, approximately $40 \mathrm{~km}$ southeast of Ocongate and $100 \mathrm{~km}$ southeast of Cusco, reported $B d$ prevalence ranging between $9 \%(\mathrm{n}=11$ frogs) and $50 \%(\mathrm{n}=2$ frogs) in populations of T. marmoratus (Seimon et al. 2007). Catenazzi et al. (under review) found that $63 \%$ of tadpoles $(\mathrm{n}=22)$ and 2 sampled metamorphs were infected with $B d$ in a stream $34 \mathrm{~km}$ east of Ocongate. Both studies reported population declines associated with $B d$ infection.

The lower zoospore loads in skins of recently sacrificed frogs probably reflected the fact that swabbed skins were often incomplete and did not include areas that are known to host large densities of zoospores, such as the pelvic patch and the innermost finger (Puschendorf \& Bolaños 2006). Most skin swabs were performed on dorsal surfaces that are less likely to shed large numbers of zoospores (Puschendorf \& Bolaños 2006). It is unclear whether skins are used for other purposes, but potential uses include food for domestic animals or fish bait. Treatments of skins in bleached water before disposal will help reduce the risk that skins facilitate the spread of $B d$.

It is difficult to evaluate the impact of the frog trade on wild frog populations and its potential to influence $B d$ epidemics in the Andes. Sale of live Telmatobius frogs is an informal business with little control from authorities in charge to protect natural resources and to enforce sanitary standards. A vendor interviewed by Angulo (2008a) indicated that she sold about 180 frogs daily and that she placed weekly orders of between 1200 and 2400 frogs. Lehr (2000) reported monthly sales of 40 to 50 frogs from vendors in Lima. Cargos of thousands of frogs are often confiscated in Lima and Puno (INRENA 2005 cited by Angulo 2008a; also see www.correoperu.com.pe/correo/nota.php?txtEdi_id=1 8\&txtSecci_parent=0\&txtSecci_id=61\&txtNota_id=230 120). Conservation biologists concerned with the spread of $B d$ have, until now, focused almost entirely on the international trade in live, farmed frogs, such as Lithobates catesbeianus (Schloegel et al. 2009), and have proposed that these live animals serve as vectors for the introduction of $B d$ and ranaviruses into new regions (Mazzoni et al. 2003, Schloegel et al. 2009). We believe that the more localized live trade of amphibians in highly diverse regions such as the Andes may also be playing an important role in the spread of $B d$.
Although the trade in Telmatobius occurs at a much reduced numerical and geographic scale compared to $R$. catesbeiana, the proximity of local Telmatobius markets to highly diverse amphibian assemblages (Tropical Andes Biodiversity Hotspot; Myers et al. 2000) poses a significant threat to amphibian conservation in the region. Local trade of live amphibians may also contribute to the spread of $B d$ and may pose a significant threat in other highly diverse amphibian areas throughout the world.

Acknowledgements. We thank the Dirección de Gestión Forestal y de Fauna Silvestre for research and collecting permits and T. Cheng and N. Reeder for laboratory assistance. Fieldwork was supported by grants from the Amazon Conservation Association, the Rufford Small Grants Foundation, the Chicago Board of Trade Endangered Species Fund, and the Amphibian Specialist Group. Analysis of real-time PCR assays for chytridiomycosis detection was supported by NSF grant EF-0723563 as part of the joint NSF-NIH Ecology of Infectious Disease Program. A.C. was supported by a postdoctoral fellowship from the Swiss National Science Foundation (116305).

\section{LITERATURE CITED}

Alford RA, Richards SJ (1999) Global amphibian declines: a problem in applied ecology. Annu Rev Ecol Syst 30: 133-165

Angulo A (2008a) Consumption of Andean frogs of the genus Telmatobius in Cusco, Peru: recommendations for their conservation. TRAFFIC Bull 21:95-97

Angulo A (2008b) Conservation needs of Batrachophrynus and Telmatobius frogs of the Andes of Peru. Conserv Soc 6:328-333

- Barrionuevo S, Mangione S (2006) Chytridiomycosis in two species of Telmatobius (Anura: Leptodactylidae) from Argentina. Dis Aquat Org 73:171-174

Barrionuevo JS, Aguayo R, Lavilla EO (2008) First record of chytridiomycosis in Bolivia (Rhinella quechua; Anura; Bufonidae). Dis Aquat Org 82:161-163

Berger L, Speare R, Daszak P, Green DE and others (1998) Chytridiomycosis causes amphibian mortality associated with population declines in the rainforests of Australia and Central America. Proc Natl Acad Sci USA 95:9031-9036

Boyle DG, Boyle DB, Olsen V, Morgan JAT, Hyatt AD (2004) Rapid quantitative detection of chytridiomycosis (Batrachochytrium dendrobatidis) in amphibian samples using real-time Taqman PCR assay. Dis Aquat Org 60:141-148

> Bustamante MR, Ron SR, Coloma LA (2005) Cambios en la diversidad en siete comunidades de anuros en los Andes de Ecuador. Biotropica 37:180-189

Catenazzi A, Lehr E, Rodriguez LO, Vredenburg VT (in press) Batrachochytrium dendrobatidis linked to the collapse of anuran species richness and abundance in the upper Manu National Park, southeastern Peru. Conserv Biol

Daszak P, Cunningham AA, Hyatt AD (2003) Infectious disease and amphibian population declines. Divers Distrib 9:141-150

Daszak P, Strieby A, Cunningham AA, Longcore JE, Brown CC, Porter D (2004) Experimental evidence that the bullfrog (Rana catesbeiana) is a potential carrier of chytridiomycosis, an emerging fungal disease of amphibians. Herpetol J 14:201-207 
De la Riva I, Lavilla EO (2008) Conservation status of the Andean frogs of the genera Telmatobius and Batrachophrynus. In: Stuart SN, Hoffmann M, Chanson JS, Cox NA, Berridge RJ, Ramani P, Young BE (eds) Threatened amphibians of the world. Lynx Edicions, Barcelona (in association with IUCN and Conservation International), p 101

Garner TW, Perkins MW, Govindarajulu P, Seglie D, Walker S, Cunningham AA, Fisher MC (2006) The emerging amphibian pathogen Batrachochytrium dendrobatidis globally infects introduced populations of the North American bullfrog, Rana catesbeiana. Biol Lett 2:455-459

Hanselmann R, Rodriguez A, Lampo M, Fajardo-Ramos L, Aguirre AA, Kilpatrick AM, Rodriguez JP, Daszak P (2004) Presence of an emerging pathogen of amphibians in introduced bullfrogs (Rana catesbeiana) in Venezuela. Biol Conserv 120:115-119

> Hyatt AD, Boyle DG, Olsen V and others (2007) Diagnostic assays and sampling protocols for the detection of Batrachochytrium dendrobatidis. Dis Aquat Org 73:175-192

Kriger KM, Hero JM, Ashton KJ (2006) Cost efficiency in the detection of chytridiomycosis using PCR assay. Dis Aquat Org 71:149-154

La Marca E, Lips KR, Lötters S, Puschendorf R and others (2005) Catastrophic population declines and extinctions in Neotropical harlequin frogs (Bufonidae: Atelopus). Biotropica 37:190-201

Lehr E (2000) Zur Nutzung einiger Amphibien- und Reptilienarten in Peru. Reptilia 24:40-46

Lehr E (2005) The Telmatobius and Batrachophrynus species of Peru. Monogr Herpetol 7:39-64

Lips KR (1998) Decline of a tropical montane amphibian fauna. Conserv Biol 12:106-117

Lips KR, Brem F, Brenes R, Reeve JD and others (2006) Emerging infectious disease and the loss of biodiversity in a Neotropical amphibian community. Proc Natl Acad Sci USA 103:3165-3170

Lips KR, Diffendorfer J, Mendelson JR III, Sears MW (2008) Riding the wave: reconciling the roles of disease and climate change in amphibian declines. PLoS Biol 6:e72

Longcore JE, Pessier AP, Nichols DK (1999) Batrachochytrium dendrobatidis gen. et sp. nov., a chytrid pathogenic to amphibians. Mycologia 91:219-227

Mazzoni R, Cunningham AA, Daszak P, Apolo A, Perdomo E, Speranza G (2003) Emerging pathogen of wild amphib-

Editorial responsibility: Alex Hyatt,

Geelong, Victoria, Australia ians in frogs (Rana catesbeiana) farmed for international trade. Emerg Infect Dis 9:995-998

Merino-Viteri A, Coloma LA, Almendáriz A (2005) Los Telmatobius (Leptodactylidae) de los Andes de Ecuador y su disminución poblacional. Monogr Herpetol 7:9-37

Morgan JAT, Vredenburg VT, Rachowicz LJ, Knapp RA and others (2007) Population genetics of the frog-killing fungus Batrachochytrium dendrobatidis. Proc Natl Acad Sci USA 104:13845-13850

Myers N, Mittermeier RA, Mittermeier CG, da Fonseca GAB, Kent J (2000) Biodiversity hotspots for conservation priorities. Nature 403:853-858

Pérez Béjar ME (2005) Crianza en cautiverio y uso sostenible de la rana gigante del Lago Titicaca (Telmatobius culeus). Monogr Herpetol 7:261-271

> Puschendorf R, Bolaños F (2006) Detection of Batrachochytrium dendrobatidis in Eleutherodactylus fitzingeri: effects of skin sample location and histologic stain. J Wildl Dis 42:301-306

> Schloegel LM, Picco AM, Kilpatrick AM, Davies AJ, Hyatt AD, Daszak P (2009) Magnitude of the US trade in amphibians and presence of Batrachochytrium dendrobatidis and ranavirus infection in imported North American bullfrogs (Rana catesbeiana). Biol Conserv 142:1420-1426

Seimon TA, Seimon A, Daszak P, Halloy SRP and others (2007) Upward range extension of Andean anurans and chytridiomycosis to extreme elevations in response to tropical deglaciation. Glob Change Biol 13:288-299

Venegas P, Catenazzi A, Siu Ting K, Carrillo J (2008) Two new species of harlequin frogs (Anura: Bufonidae: Atelopus) from the Andes of northern Peru. Salamandra 44: 163-176

von May R, Catenazzi A, Angulo A, Brown JL and others (2008) Current state of conservation knowledge on threatened amphibian species in Peru. Trop Conserv Sci 1: 376-396

> Voyles J, Young S, Berger L, Campbell C and others (2009) Pathogenesis of chytridiomycosis, a cause of catastrophic amphibian declines. Science 326:582-585

> Weldon C, du Preez LH, Hyatt AD, Muller R, Spears R (2004) Origin of the amphibian chytrid fungus. Emerg Infect Dis 10:2100-2105

Woodhams DC, Ardipradja K, Alford RA, Marantelli G, Reinert LK, Rollins-Smith LA (2007) Resistance to chytridiomycosis varies among amphibian species and is correlated with skin peptide defenses. Anim Conserv 10:409-417

Submitted: January 25, 2010; Accepted: June 10, 2010 Proofs received from author(s): July 12, 2010 